\title{
Monitorship and Collaboration: The Creation of a Development Place
}

\author{
Márcia Sueli Pereira da Silva Schneider \\ Federal University of Tocantins, Palmas, Brazil
}

\begin{abstract}
This article aims at presenting and discussing the work with monitorship as a tool to continuing teacher's formation. As foundation to the discussions, this study is based on the works developed by Vygotsky (1934/1998), Leont'ev (1904/1959), and Brookfield (1987) to understand the critical reflective principles and the language role mediating the social inter-relations. The results show that the work developed through the monitorship propitiated the teacher's reflections on the theory learnt and on how the teaching-learning process is related to the students' needs and the practice developed in the classroom. The results also show that the work developed through the monitorship allowed a more active and responsible attitude from the students in the teaching-learning process, constructing their knowledge and transforming their senses through the meaning shared socially.
\end{abstract}

Keywords: monitorship, collaboration, development, teaching-learning

\section{Introduction}

Although the text of National Educational Bases and Guidelines Law (Lei de Diretrizes e Bases Da Educação Nacional (LDB), 1996) affirms the importance to guarantee the equality of education to all citizens and recommends that the necessities of the students be taken care of, what it has been observed, with certain frequency, is that the difficulties of learning in some curricular contents tend to remain in the subsequent years, even if the intervention of the school through traditional ways of recovering the study (in regular schools), or, for instance, through the monitorship work developed at a college.

The persistence of such difficulties shows that the supra-mentioned initiatives, and even though the pedagogical work as a whole and the way it has been carried out, have not contributed to the structural development of the students, since that, it does not give autonomy in their learning, and does not help them identify their potentialities and difficulties. That is why, as Gadotti (as cited in Freire, 2001) said, the school is still working in the traditional mold, focusing on teaching and seeing the teacher as a mere transmitter of information. Education in this Cartesian method does not take into account the experience or the knowledge of the students.

This scenario started to present changes from the 20th century that brought lots of transformation and necessities to the society. In this new social configuration, the school as an epistemological centre must contribute to promoting human development. That is, the focus of learning must be to know how to interact with and relate to others, since, as Stambak (2004) said, "No one learns or teaches alone", after all, every "Man

Márcia Sueli Pereira da Silva Schneider, Ph.D., professor, Department of Language and Literature, Federal University of Tocantins. 
constitutes himself by the relations that he establishes with others" (John-Steiner \& Mahn, 1996).

So, in this new society, the school's role is to "teach to think", helping the students develop the capacity to understand and participation, that is, to develop an ethical consciousness.

Trying to contribute to this new society and this new school that has to find out new methods of teaching and new ways of pedagogical actions, this research aims at presenting and discussing the work with monistorship as a tool to continuing teacher's formation and as a tool to work with the students' difficulties.

\section{The Development of a Collaborative Work}

The theories of learning try to recognize the dynamic that involves the act of teaching and learning, starting from the understanding of the cognitive evolution of the human being to explain the relationship between the prior knowledge and the new one. Reflecting about the importance of the exchange between pairs as significant moments in the teaching-learning process take us to the concept presented by Vygotsky (1934/1998), where a vision of human development can be found based on the idea of an active organism, whose thinking is formed in a social, historical, and cultural environment. To the author, the possibilities that the environment provides to the individual are the bases to him/her to grow as a lucid and conscious person, being able to change the circumstances in his/her live, mediated by the language.

According to Vygotsky (1934/1998), the language reflects a way to notice the real in a certain time and space, and points to the way the individual learns in the circumstances he/she lives, keeping this way a double function, if on one hand it allows the communication, organizes and mediates the conduct; on the other hand, reflects thinking and stands out the importance of the cultural factors between the social relations. In this way, the confrontation between the initial conceptions with those presented by the pairs become fundamental to the appropriation of different meanings that, dialogically, will form senses to be negotiate, since that, it is through the interactions the scientific concepts can be more detailed, enriching the spontaneous concepts that take a rising way, since that they are enlarged by the scientific concepts that are historically produced.

Leont'ev (1904/1959) explained that the higher psychological process can grow from the interaction between the individuals, that is, the individual is the result of his/her own activity that is subjected to the social relations since its origin - immediate cause that gives to the human the reflection of reality - that is it, his/her consciousness. To the author, the psychological human functions are built during all his/her life through a process of interaction with his/her physical and social environment, since the human being is not only the product of his/her social context, but an active agent of it.

The social interactions understood by this perspective allow us to think in a human being that is in constant transformation and through the social interactions he/she gets new meaning and look to live in society. In this way, the development of a work on this view takes us to the understanding that the individual constitutes himself/herself through the collaboration with "others", since that the dialog becomes a "permanent tool in an emancipatory action, which the individual finds each other to transform the world in collaboration" (Freire, 2000).

To Brookfield (1999), in a democratic process where everybody has the opportunity of positioning, the argumentation - that happens through a collaborative way with others-becomes a value way to show the diversity of opinions, to explicit the problems to be analysed, and to find out a solution for them collaboratively. This shared knowledge, where new knowledge and meanings are produced, becomes the "bridge" to a cognitive construction of the group. 


\section{What Is a Monitorship?}

It is important to say that the following text is based on research realized on documents of several educational institutions in Brazil that have several guidelines to develop the work with monitorship.

Trying to understand how the work with monitorship happens, it could be noticed that this work normally occurs in higher education, with fixed guidelines. Although some peculiarities, the work is understood as a formative activity that aims to contribute to the development of the pedagogical skill, help students in the process of learning and in the production of knowledge, make possible to the student monitor an experience with the teaching-learning process, make possible the collaborative work between the teacher and the student monitor, and help the teacher in the research work.

However, after lots of studies, it can be seen that the monitorship activity normally happens in an extra class action in order to try to retrieve activities that had happened during the class. But this action is non-functional by a set of reasons:

1. Most institutions do not have money to subsidize the student monitor;

2. The student monitor has to work about 8-15 hours per week without damage to his/her didactic activity;

3. Several students cannot participate in the monitorship session, because it is offered in counter-turn or before the class starts.

In a post-graduation course, the teaching practice is almost the same as the work developed in the graduation course, since it aims to prepare the post-graduate students to get skills to work with in higher education.

In distance programs, the monitorship gets an important role since it tries not only to stimulate and guide the students, but also to facilitate the learning situations.

It can be seen that the work from this view can be understood as an activity that helps the teaching-learning process, as a following of the formative activities, or as a possibility of practicing to the student monitor. However, before being a teacher's assistant, a programmer, or a learning facilitator, the student monitor must understand that the teaching-learning relationship happens in a special and unique way in each class, through a joint work between teacher-students and students-students.

\section{The Monitorship Work in a New View}

According to Antunes (2002), the school must be a tool to impart knowledge to the students. However, it is observed that the pedagogical actions have not contributed to this appropriation and other actions must be put in practice to finish the process. It can be seen that the monitorship has been one of these actions, but it seems to be insufficient.

Departing from a work developed in group, Faria (2003) proposed a new way of work with monitorship, where every participant could have an active and collaborative role in the teaching-learning process. On this new view, the author presents a work where the student's monitor work happens concomitantly with the teacher work in class, requiring an active and collaborative participation of all-teacher and students, student monitor and teacher, student and student, and student monitor and students-during the teaching-learning process, easing the relations of power and rising the participants' role and the responsibility of the group.

Faria (2003) affirmed that the first step is to identify students that can become monitor. After that, these students must be shared between the groups. The author proposed that these groups would be formed in a 
homogenous way, in this way, the student monitor could help them in an equalitarian form, without causing anxiety or waiting.

To the author, the work developed in this mold propitiates a better advice during the activities in class, besides promoting more effective actions with the students that start in an unfavorable position, giving them the opportunity to get good results.

According to Celani (2005), the work developed in groups can be more productive to develop ethical procedure and consciousness, since the students can experience learning with different cultures or habits that the colleagues bring to class. As the teacher, this experience can help him/her see clearly his/her action in class, giving him/her an opportunity to reflect about it.

\section{The Development of the Monitorship Work}

The data analyzed were collected in 2005 during a work developed in a 4th grade class of a Basic Level I (9-10 years old) in a municipal school in Conceição dos Ouros, Minas Gerais, Southeast Brazil. Two face-to-face reflective sessions $(29 / 04 / 2005 ; 04 / 06 / 2005)$, an initial description of the teacher, and two letters that the students sent to the researcher were analysed.

The analyses were developed through evaluation mechanisms, such as opinion, value, feelings, discursive position, modal expressions, and linguistics choices (Bronckart, 1997/1999). So, this study focused on the senses produced during the discourse with values:

(a) Epistemic - shows the certainty or truth level;

(b) Psychological—shows the cognitive level;

(c) Appreciative - points the subjective position of the speaker;

(d) Pragmatic - shows the intention of the speaker;

(e) Deontic - takes into account everything the speaker thinks is a necessity, obligation, etc..

Senses about the teaching of English in basic level. For this section, two face-to-face reflective sessions $(29 / 04 / 2005 ; 04 / 06 / 2005)$ and the initial description were analysed. During the analyses, it can be seen that the teacher shows the insecurity that lot of English teachers normally show when they have to teach English for basic level students.

As can be seen from Table 1, through the subjective adjective ("afraid") following by the modifier/intensifier ("very"), the teacher shows insecurity to develop her work. This insecurity that exposes her emotional reaction to develop the work is reinforced by her explanation ("Because I have never been teaching"), or by feeling afraid in accepting the job ("I was a little bit afraid").

Table 1

Initial Description (Part I)

In 2005, I was invited to teach English to children from 5 to 10 years old in a public school in Conceição dos Ouros. I was very afraid (Psychological) ${ }^{1}$, because I have never been teaching (Explaining/Epistemic) children with these age.

The sense of the teacher about "a different work" in classroom is showed by her necessity or obligation in "have to do something different" (see Table 2) and the criticism that she does to the pedagogical practice is implied in her discourse when she speaks about the didactical material used and how the classes were worked, comparing them with what she was learning at the college (see Table 3).

${ }_{1}$ The words in bold during the analyses show the level of reflective proccess. 
Table 2

Reflective Session (04/06/2005)

T: As I am studying modern language ... so they (school) called me ... invited me ..., so I was a little bit afraid in accepting it (Certainty/Epistemic), because I said ... if I cannot do it well (Appreciative), it is better not to accept (Epistemic) so I said but I do not have knowledge (Epistemic)... What I can do? I do not want to teach in the same way (Pragmatic), because if they (school) want other teacher... I do not know ... I have to work in a different way (Deontic) ... I have to do something different (Deontic) ... because it is no use doing the same way ... they (school) want something different....

\section{Table 3}

Initial Description (Part II)

T: Besides, the didactical material that was being used, and the way the class of English was being worked, were not in accordance with everything I have studied at a college (Certainty/Epistemic).

The analyses, on one hand, show the sense of the teacher which indicates a traditional teaching in the school, on the other hand, through her internal conflicts, show her consciousness of having to promote changes. Her perception of it takes her to try to understand and reflect about the context in which she would work (see Table 4).

Table 4

Reflective Session (24/05/2005, Part I)

T: I have already been thinking (Psychological) "My God!... what...". We have already had a different thinking (Certainty/Epistemic) from that teacher that was working there ... because I do not know ... we are here at a college ... we see every time that we have to work something interesting (Deontic) ... that we have to work new things (Deontic) ... it is different ... né ... so I have already been thinking (Psychological) that I would find a way to work in a different way (Intention/Pragmatic).

Her conflict, understood in a social, historical, and cultural perspective (Vygotsky, 1934/2001), takes us to notice how the environment makes possible the transformation and the evolution of the thinking, since when she accepted to work with children in basic level, she tried to understand and reflect about the context in which she would work, and from that, find solutions to change it.

The collaborative work between the researcher and the teacher to develop a monitorship work in classroom. The analyses of the reflective session (29/04/2005) (see Tables 5 and 6) review the interaction happened between the researcher and the teacher to think about the work with monitorship. The analyses show the researcher's worry in developing the work, such as group formation, student monitor turnrounds, procedure of the teacher during the work, and so on.

Table 5

Reflective Session (24/05/2005, Part II)

R: (...) Which the criteria for the distribution of the students in groups ... ok? ... because you are going to think ... I do not know ... 30 students in how many groups we are going to divide them ... it cannot be a big group.

Table 6

Reflective Session (24/05/2005, Part III)

R: (...) Which the criteria for the monitor ... a thing now you are talking about this group ... the turnrounds ... because they will no be in a only one group.

T: Ok ... so ... because ... we have to do the turnround.

The participation and co-responsibility of the researcher in developing the work is showed by the factive verb used ("We are going to divide them"). 
During the interaction, it can be seen that the researcher tried to involve the teacher, creating a zone (Vygotsky, 1934/2001) for building the meanings collaboratively, when, for instance, making use of challenge questions, asking for explanation, and giving the teacher the opportunity to reflect and talk about her initial attempt of work.

The analyses in Table 7 show that the first problem found reflects what normally happen in class when they have to work in group - do not accept the leader or they choose who they are going to work with. These show up the difficulty in developing a work in group and the necessity of developing in the students the necessary factors that take them to relate to or interact with others to work together (Delors, 2003).

Table 7

Reflective Session (24/05/2005, Part IV)

R: Have you tried to put some ... and what happened?

T: I divided the class because I ... at first, because the girls would like to work together because the class has less girls ... I am going to talk with them ... why not mix ... so that ... one minute ... so we formed the groups and I tried this way ... that student that I thought that would show a big facility ... leadership ... so ... I think this to choose and put them into the groups ... I think that ... I thought that ... in my class ... I thought we got a good result ... I think it was very well ... but two groups can't work together ... they can't ....

R: Why?

T: Because the students do not want... Got it? One student does not accept to work. ... He says "I do not want you as a leader" ... Got it?... "Otherstudents could lead me but not you"... Sometimes, it happens ... so ... I cannot ... I cannot do it ... né?

The difficulty pointed by the teacher shows the culture of the school where the work is realized in a traditional mold - Students sitting in a line and the teacher as a holder of knowledge. It shows the difficulty of running away from the pedagogical practice based on Cartesian method.

Faced with it, the researcher tries to find ways to solve the problem and show the teacher the positive points in a work developed in group; tries to create a context to clarify the sense of working with monitorhip. For that, the researcher reinforces the necessity of turnrounds the monitor in the groups, pointing that this turnround as a possible solution for the problem and as a tool to the teacher to rethink the group formation.

As can be seen from Table 8, during the reflective process, the sense of the teacher in relation to the turnround and the work in group is changed from the meanings shared with the researcher. This reflective process shows that the constant built and transformation of the human being happen through the interaction, and the opportunities that the teacher and the researcher had for positioning, put their opinions, confronting the problem, giving them the opportunity to find the answer, through a collaborative process (Brookfield, 1999). This reflective process also shows how the learning should be - knowing how to relate to and interact with others (Stambak, 2004; John-Steiner \& Manh, 1996), and the responsibility of all in the development.

This responsibility can be seen in the letters (see Tables 9 and 10) that were sent to the researcher by the students where they show the evaluation of the work developed in group and their sense in relation to the monitor's role and the different habits of learning.

On one hand, the work provides that the teacher and the researcher shared meanings, changed their senses, and built their knowledge, on the other hand, it provides that the teacher took the classroom this practice, trying to stimulate the students to do the work, letting them to give their position and, by negotiation, find the solution for the problem, that is it, letting them to build their knowledge collaboratively. 
The teacher's position is exactly what is hoped for a pedagogical practice in this new conception of education, that is it, to make the students realize that they are active agents in their knowledge building (see Table 11).

Table 8

Reflective Session (24/05/2005, Part V)

R: (...) A thing now you are talking about these groups ... the turnround ... because they (student monitor) cannot only stay with that group.

T: Ok ... so ... because it have to do the turnround?

R: Yes.

T: So ... I thought exactly this ... because (...) but I think this way ... for instance ... if I put the monitor ... a child that has more facility there ... I put him ... he (monitor) developed in that activity that I asked ... that group did it very well ... everybody (students of the groups) contributed ... that group will have a different development from the other groups ... it is not only responsibility of the monitor ... was the group ... they are going to have a different development from the group where there is no contribution ... so I have to do the turnround.

R: So ... we also have ... we have to think ... because it always have in class the student that do not want to work ... do not like to work with "that" student ... but why do not like?

$\mathrm{T}$ : Yes ... this work.

$\mathrm{R}$ : This is the point ... the work with monitorship also gives condition to you work in this point ... it is to bring that excluded student to the group.

T: It's really true!

Table 9

Letter of the Student $X$

(...) I like English class, and I like to work in group. I like to work in group because I teach and learn with my colleagues. But I know that lots have difficulties.... It is necessary to study a lot, learn new words.

(...) When I am working in a group, I do not tell them off, I just help them, I talk with them, I explain, but I do not do the activity for them, because they will never learn.

Table 10

Letter of the Student $Y$

(...) I think that this project is very interesting. Working in group is nice but there are children that think the monitor has to do everything for them, but not, the monitor is that person that knows a little bit more than the others, as you said in the video, the monitor has to help the other and not do the job.

Table 11

Reflective Session (04/06/2005)

T: (...) I noticed and I said "Guys! do it too ... after you talk about the answer, because it is no use he (monitor) does because you will not have another opinion”! (...) Let us think ... look back to the text (...).

\section{Conclusion}

Teachers are constantly in a new context of work and by lots of reasons, they feel unprepared to act with this new situation. This difficulty lies, principally, in understanding the necessities of the students and the relation between theory and practice.

It can be seen that monitorship, while as a tool for the reflective process, provided that new meanings were produced from sharing senses; provided the reflection about the teaching-learning process in the school and to the teacher's realization that he/she was not the principal part of it.

While as a tool of the teaching-learning process, the work developed through the monitorship contributed to students' realization that they are a responsible part of the process and knowledge building occurs through sharing senses. 


\section{References}

Antunes, C. (2002). Vygotsky, quem diria?! Em minha sala de aula (Vygotsky, who would have thought it?! In my classroom). Petrópolis, R.J.: Vozes.

Bronckart, J. P. (1997/1999). Atividade de linguagem, textos e discursos: Por um interacionismo sócio-discursivo (Language activity, texts and discourse: For a socio-discursive interactionism). São Paulo: EDUC.

Brookfield, S. (1987). Developing critical thinkers: Challenging adults to explore alternative ways of thinking and acting. San Francisco, C.A.: Jossey-Bass Publishers.

Brookfield, S. (1999). Discussion as a way of teaching: Tools and techniques for democratic classrooms. São Francisco, C.A.: Jossey-Bass Publishers.

Celani, M. A. A. (2005). Questões de ética na pesquisa em lingüística aplicada (Ethical issues in applied linguistics research). Linguagem \& Ensino, 8(1), 101-122.

Delors, J. (2003). Educação: Um tesouro a descobrir (Education: A treasure to be found). São Paulo: Cortez.

Faria, J. P. (2003). A monitoria como prática colaborativa na universidade (Monitoring as collaborative practice at the university) (Master's thesis, LAEL-PUC/SP).

Freire, P. (2000). Pedagogia do oprimido (Pedagogy of the oppressed). São Paulo: Paz e Terra.

Freire, P. (2001). Educação e mudança (Education and changing). São Paulo: Paz e Terra.

John-Steiner, V., \& Mahn, H. (1996). Sociocultural approaches to learning and development: Vygotskian framework. Retrieved from http://webpages.charter.net/schmolze1/vygotsky/johnsteiner.html

Lei de Diretrizes E Bases Da Educação Nacional (LDB). (1996). LEI no 9394-96 de Dezembrode 1996 (Law No. $9394-96$ of December 1996). Retrieved from http://www.planalto.gov.br/CCIVIL/leis/L9394.htm

Leont'ev, A. N. (1904/1959). O desenvolvimento do psiquismo (Psyche development). São Paulo: Editora Moraes Ltda.

Stambak, M. (2004). Dar vontade de aprender a todos: O desafio do cresas (Making everyone want to learn: The Cresas' challenge). In F. Platone, \& M. Hardy (Eds.), Ninguém ensina sozinho: Responsabilidade coletiva na creche, no ensino fundamental e no ensino médio (No one teaches by themselves: Collective responsibility in the nursery, elementary school and high school) (pp. 23-33). Porto Alegre: Artmed.

Vygotsky, L. S. (1934/1998). A formação social da mente: O desenvolvimento dos processos psícológicos superiors (The social formation of the mind: The development of higher psychological processes). São Paulo: Martins Fontes.

Vygotsky, L. S. (1934/2001). A psicologia e o mestre (Psychology and the master). In L. S. Vygotsky (Ed.), Psicologia pedagógica (Pedagogical psychology). São Paulo: Martins Fontes. 